\section{Kronen på verket i histologi}

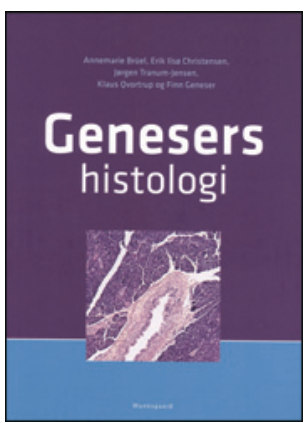

Finn Geneser, Annemarie Brüel,

Erik Ilsø Christensen et al.

Genesers histologi

761 s, ill. København: Munksgaard Danmark, 2012. Pris DKK 998

ISBN 978-87-628-0396-1

Denne histologiboken er nok særlig rettet mot studenter i medisin, men alle studentgrupper som studerer generell cellebiologi og histologi, vil med stort utbytte kunne benytte den. Den egner seg meget bra så vel i starten av studiet som for den viderekomne student. Jeg vil tro at den også passer som et praktisk oppslagsverk for erfarne lærere og studenter i faget.

Boken bygger på den meget pedagogisk vellykkede Histologi på molekylcerbiologisk grunnlag, publisert av Finn Geneser i 2002. Boken benytter mye av den samme teksten og de samme illustrasjonene. Likevel med den tydelige forskjell at fotografier jevnt over har bedre kvalitet, og de tegnede illustrasjonene har til dels meget raffinerte, detaljerte forskjeller fra den tidligere boken. Vi finner også mange nye elektronmikroskopiske bilder. Illustrasjonene er i det hele meget gode og forklarende og har med også helt ny viten i faget.

De siste tiårene har det vært en enorm fremgang i tilgjengelig kurslitteratur. Med Genesers nå utvidede og mer presiserende utgave har vi fătt en nordisk «krone på verket». Boken er lettforståelig, svært godt pedagogisk anlagt og god på beskrivelse av funksjonell cellebiologi og den spesielle organhistologien. Her er også gode og generelle forklaringer av sykdomsprosesser knyttet til ulike vev og organer, som selvsagt særlig er rettet mot medisinstudenter, men som også bygger opp under den generelle biologiske kunnskapen for andre interesserte studentgrupper.

Per Gøran Krüger

Institutt for biomedisin

Universitetet i Bergen

\section{Cytologi og histologi - nyttig for studenter}

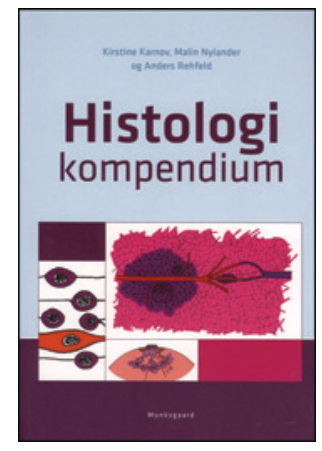

Kristine Karnov, Malin Nylander,

Anders Rehfeld

Histologi kompendium

300 s, ill. København: Munksgaard Danmark,

2012. Pris DKK 298

ISBN 978-87-628-1116-4

Dette histologikompendiet er et supplement til Genesers Histologi (se egen anmeldelse). Kompendiet er inndelt i samme kapitler og henviser til figurene i denne læreboken. Kompendiet er nok derfor mest nyttig for studenter som

benytter Genesers Histologi som lærebok. Kompendiet har likevel så mange - om enn kortfattede - generelle anatomiske henvisninger at det kan være nyttig for studenter med andre lærebøker som basis.

Forfatterne har valgt en særdeles prisverdig «åpen» design som betyr at hver side er oversiktlig med tydelige overskrifter og en indre kapittelinndeling. Derav også størrelsen på boken som med en konvensjonell design nok ville kunne rommes på 100 sider. Dette elegant gjennomførte pedagogiske opplegget kan gjøre kompendiet til et nyttig verktøy for alle studenter i cytologi og histologi.

Per Gøran Krüger

Institutt for biomedisin, Universitetet i Bergen 